\title{
Surveys of MPs and Senators in the Parliament of the Czech Republic between 1993 and 2005
}

\author{
LUKÁŠ LINEK* \\ Institute of Sociology, Academy of Sciences of the Czech Republic
}

\begin{abstract}
The article provides an overview of the surveys conducted among MPs of the Czech parliament between 1993 and 2005. It describes seven surveys conducted among MPs in the Chamber of Deputies and one survey among members of the Senate. Particularly in the early 1990s such surveys were conducted or at least run and financed by researchers from outside the Czech Republic. These surveys are characterised from the perspective of the content of the observed variables and from the perspective of representativeness, which is demonstrated by the percentage of MPs taking part in the survey. The article also contains references to texts that have made use of the data provided by these MP surveys. Sociologický časopis/Czech Sociological Review, 2005, Vol. 41, No. 3: 487-497
\end{abstract}

Questionnaire surveys focusing on the opinions and behaviour of MPs have in recent years become an important source of information for considerations and reflections on the development and style of democracy in individual countries. This trend has also surfaced in the Czech Republic, where, particularly during the first electoral term of the Chamber of Deputies, a number of questionnaire surveys were carried out among MPs. These surveys were usually conducted as a part of projects aimed at examining the institutionalisation of democracy, or specifically the institutionalisation of parliament as one of the fundamental political institutions in the newly established democratic states. The aim of the following text is to present the surveys conducted among MPs and senators that involved systematic questioning, where the survey population was made up of all the members of the targeted chamber. Consequently, the summary does not cover those surveys that concerned, for example, only members of particular committees or parliamentary party groups. Also, this summary of surveys is not the intended to be exhaustive; there may be other questionnaire surveys of MPs, but the author has no information on them and consequently they are not included here.

* Direct all correspondence to: Lukáš Linek, Institute of Sociology, Academy of Sciences of the Czech Republic, Jilská 1, Prague, 110 00, Czech Republic, e-mail: Lukas.Linek@soc.cas.cz

C Sociologický ústav AV ČR, Praha 2005 


\section{From 1993 to 1996: Studies on the Czech parliament by Western European experts}

During the first electoral term of the Chamber of Deputies of the Parliament of the Czech Republic four surveys were conducted, only one of which was also accompanied by a parallel survey of attitudes among the general population using almost identical variables, and two of which were part of comparative studies organised abroad. The first survey of MPs was organised by the Sociology of Politics Department at the Institute of Sociology AS CR, headed by Lubomír Brokl and in co-operation with Prof. Kees Niemöeler from the Centre for Electoral Studies in the Department of Statistics and Methodology PSCW of the University of Amsterdam. Data was collected with the support of a research grant from the Research Support Scheme of the Central European University (grant title: 'The Party System and Parliament in the 1992 Election Year') and the University of Amsterdam. This research was carried out simultaneously in the Slovak National Council. The fieldwork was conducted in March 1993 by Factum (a marketing and market research company). A total of 136 deputies took part in the research (i.e. $68 \%$ of the total number of 200 deputies). A relatively higher number of deputies in left-wing parties took part in the research, while conversely only a few deputies from the parliamentary party groups of extremist and nationalistic parties participated (see Table 1).

The basis for the first comprehensive questionnaire was the research on German and Dutch parliaments carried out at the end of the 1980s and in the early

Table 1. The party structure of the Institute of Sociology survey sample in 1993

\begin{tabular}{lcc}
\hline Party membership at the time of interview & No. of interviews & $\begin{array}{c}\text { Percentage of } \\
\text { total interviews }\end{array}$ \\
\hline Civic Democratic Party (ODS) & 52 & 38.2 \\
Communist Party of Bohemia and Moravia (KSČM) & 33 & 24.3 \\
Czech Social Democratic Party (ČSSD) & 16 & 11.8 \\
Christian-Democratic Union - Czechoslovak & & 5.9 \\
People's Party (KDU-ČSL) & 8 & 5.9 \\
Movement for Self-governing Democracy & & 5.1 \\
of Moravia and Silesia (HSDMS) & 8 & \\
Christian Democratic Party (KDS) & 7 & 2.9 \\
Association for the Republic - Czechoslovak & & 1.5 \\
Republican Party (SPR-RSČ) & 4 & 1.5 \\
Czechoslovak Socialist Party (ČSS) & 2 & 0.7 \\
Agricultural Party (ZS) & 2 & 0.7 \\
Civic Democratic Alliance (ODA) & 1 & 2.2 \\
Moravian Party (MS) & 1 & 100.0 \\
No party affiliation & 2 & \\
Total & 136 & \\
\hline
\end{tabular}

Source: Data from a survey of MPs in the Parliament of the Czech Republic in 1993 [Institute of Sociology, Academy of Sciences of the Czech Republic 1993]; author's calculations. 
1990s. The questionnaire was modified to suit the Czech context and contained a total of 86 questions. The subjects studied in the research included the structure of MPs' activities, how demanding the activities were on their time, the form and frequency of contacts MPs had with voters and interest groups, the importance of the individual activities MPs engaged in, the functions of parliament and an evaluation of its performance, and information sources. The survey also included questions on the role of political parties in decision-making and the voting of PPGs and MPs, on the role of party leaders and parliamentary groups in parliament, and on contacts with the government, means of influence, and on MPs' ambitions. An important part of the survey was asking MPs to position themselves and position the voters of all the relevant parties on the left-right political scale.

In 1993 MPs were presented with a questionnaire survey that was conducted as part of a comparative project on 'The Institutionalisation of Parliamentary Democracy in Poland, Hungary, the Czech Republic and Slovakia'. This research was organised by the Department of Political Science of Leiden University. Data col-

Table 2. The party structure of the Kopecký survey sample in 1993

\begin{tabular}{|c|c|c|c|c|}
\hline \multirow[b]{2}{*}{ Political Party } & \multicolumn{2}{|c|}{ Elected as } & \multicolumn{2}{|c|}{ Belongs to } \\
\hline & $\begin{array}{l}\text { No. of } \\
\text { interviews }\end{array}$ & $\begin{array}{c}\text { Percentage } \\
\text { of total } \\
\text { interviews }\end{array}$ & $\begin{array}{l}\text { No. of } \\
\text { interviews }\end{array}$ & $\begin{array}{c}\text { Percentage } \\
\text { of total } \\
\text { interviews }\end{array}$ \\
\hline ODS-KDS & 60 & 35.7 & - & - \\
\hline Civic Democratic Party (ODS) & - & - & 52 & 31.0 \\
\hline Christian Democratic Party (KDS) & - & - & 8 & 4.8 \\
\hline Left Block (LB) & 35 & 20.8 & 35 & 20.8 \\
\hline Czech Social Democratic Party (ČSSD) & 13 & 7.7 & 14 & 8.3 \\
\hline $\begin{array}{l}\text { Association for the Republic - } \\
\text { Czechoslovak Republican Party (SPR-RSČ) }\end{array}$ & 13 & 7.7 & 8 & 4.8 \\
\hline $\begin{array}{l}\text { Christian-Democratic Union - } \\
\text { Czechoslovak People's Party (KDU-ČSL) }\end{array}$ & 12 & 7.1 & 12 & 7.1 \\
\hline Liberal Social Union (LSU) & 12 & 7.1 & 9 & 5.4 \\
\hline $\begin{array}{l}\text { Movement for Self-governing Democracy } \\
\text { - Association for Moravia and Silesia } \\
\text { (HSD-SMS) }\end{array}$ & 12 & 7.1 & 7 & 4.2 \\
\hline Civic Democratic Alliance (ODA) & 11 & 6.5 & 11 & 6.5 \\
\hline Liberal Social National Party (LSNS) & - & - & 4 & 2.4 \\
\hline $\begin{array}{l}\text { Movement for Self-governing Democracy } \\
\text { of Moravia and Silesia (HSDMS) }\end{array}$ & - & - & 7 & 4.2 \\
\hline No party affiliation & - & - & 1 & 0.6 \\
\hline Total & 168 & 100.0 & 168 & 100.0 \\
\hline
\end{tabular}

Source: Data file from the study 'The Institutionalisation of Parliamentary Democracy in Poland, Hungary, the Czech Republic and Slovakia 1993' [Kopecký 1993]; author's calculations. 
lection took place between September and December 1993 and was again organised by Factum. A total of 168 MPs took part in the research. In comparison with the survey headed by Lubomír Brokl in 1993, this survey managed to attract more MPs from ODA and KDU-ČSL.

The questionnaire contained 108 questions, which focused primarily on the procedural content of politics and were not designed to determine political attitudes towards the content of politics (state regulation, social policy, etc.). The survey therefore reveals MPs' viewpoints on the electoral system, the President, the functions of parliament, the organisation of parliamentary clubs, the existence of party factions, the method of voting, the capacity of MPs to influence the positions and politics of the government, and the avenues whereby various interest groups may be able to shape laws. Other sets of questions addressed the roles of MPs, their relationship to voters, and their workload. Petr Kopecký used the results of this survey for what is to date the most comprehensive publication on the institutionalisation of parliament, the links between individual political institutions, and party competition in the Czech Republic [Kopecký 2001].

Table 3. The party structure of the Miller - White - Heywood survey sample in 1994

\begin{tabular}{|c|c|c|c|c|}
\hline \multirow[b]{2}{*}{ Political Party } & \multicolumn{2}{|c|}{ Elected as } & \multicolumn{2}{|c|}{ Belongs to } \\
\hline & $\begin{array}{l}\text { No. of } \\
\text { interviews }\end{array}$ & $\begin{array}{l}\text { Percentage } \\
\text { of total } \\
\text { interviews }\end{array}$ & $\begin{array}{c}\text { No. of } \\
\text { interviews }\end{array}$ & $\begin{array}{l}\text { Percentage } \\
\text { of total } \\
\text { interviews }\end{array}$ \\
\hline Civic Democratic Party (ODS) & 49 & 36.6 & 48 & 35.8 \\
\hline LB / KSČM & 25 & 18.7 & - & - \\
\hline Left Block (LB) & - & - & 18 & 13.4 \\
\hline $\begin{array}{l}\text { Communist Party of Bohemia } \\
\text { and Moravia (KSČM) }\end{array}$ & - & - & 7 & 5.2 \\
\hline Czech Social Democratic Party (ČSSD) & 13 & 9.7 & 15 & 11.2 \\
\hline Liberal Social Union (LSU) & 11 & 8.2 & 4 & 3.0 \\
\hline $\begin{array}{l}\text { Movement for Self-governing Democrac } \\
\text { Association for Moravia and Silesia } \\
\text { (HSD-SMS) }\end{array}$ & 9 & 6.7 & - & - \\
\hline Czech-Moravian Party of Center (ČMSS) & & & 3 & 2.2 \\
\hline $\begin{array}{l}\text { Association for the Republic - Czechosl } \\
\text { Republican Party (SPR-RSČ) }\end{array}$ & ak & 6.0 & 5 & 3.7 \\
\hline Christian Democratic Party (KDS) & 7 & 5.2 & 7 & 5.2 \\
\hline $\begin{array}{l}\text { Christian-Democratic Union - Czechosl } \\
\text { People's Party (KDU-ČSL) }\end{array}$ & ak & 4.5 & 7 & 5.2 \\
\hline Civic Democratic Alliance (ODA) & 6 & 4.5 & 8 & 6.0 \\
\hline Liberal Social National Party (LSNS) & - & - & 4 & 3.0 \\
\hline No party affiliation & - & - & 8 & 6.0 \\
\hline Total & 134 & 100.0 & 134 & 100.0 \\
\hline
\end{tabular}

Source: Data file from the project 'Values and Political Change in Post-Communist Europe' [Miller, White and Heywood 2000]; author's calculations. 
In 1994 another survey was conducted among MPs, which was part of a large comparative study on political values in post-communist countries, encompassing the Czech Republic, Slovakia, Hungary, Ukraine, and Russia. This research was sponsored by the British Economic and Social Research Council, which provided support to William L. Miller, Stephen White and Paul Heywood for a survey on the attitudes of the public and elites in these five states (grant no. R000233538: 'Values and Political Change in Post-Communist Europe'). A book on attitudes in post-communist societies was published in 1998 [Miller, White and Heywood 1998]. In the Czech parliament the survey was organised by the Prague-based company Opinion Window and conducted in the autumn of 1994 (11 October - 3 November 1994). A total of 134 out of 200 MPs took part in the survey.

The questions in this questionnaire almost exclusively concerned the four different groups of political attitudes among MPs. First, the research examined MPs' views on democracy, elections, the size of the party system, government accountability, the banning of some political parties and trust in political and social institutions. Second, the research ascertained MPs' attitudes on the regulation of the economy, preferences for state or market regulation of different sectors of the economy and services, attitudes on unemployment, and the responsibility of the state for the provision of social services. Third, the authors examined feelings of nationalism among MPs, and fourth it questioned MPs on their views about the degree of preferred freedom and the state restriction of rights.

Among the main findings in the research was that at the time of the survey there was less support for socialist ideas among MPs than among the public. Socialism was approximately $30 \%$ more popular among the public in four countries surveyed than among MPs (the least difference was in the Czech Republic at 23\%; $28 \%$ of MPs in the Czech Republic endorsed socialist values). MPs in post-communist parliaments much more strongly supported the market economy than did the public and they were more optimistic about government reforms and the future [Miller, White and Heywood 1998: 177-190]. With regard to the future development of state funding for political parties in the Czech Republic it is no surprise to find that there was considerably more support for this method of funding among MPs (78\% among MPs and only 22\% among the public) [Miller, White and Heywood 1998: 189].

In 1996 the Sociology of Politics Department at the Institute of Sociology AS $\mathrm{CR}$, headed by Lubomír Brokl, conducted a second survey of MPs from the first electoral term. The research was supported by a grant from the Grant Agency of the Czech Republic (grant no. 403/96/0388 on 'Representatives in the Parliament of the Czech Republic 1996. The Second Stage of Research'), and the survey was conducted in co-operation with the East Carolina University in Greenville and with Charles University. The research was carried out between February and April 1996, at the end of the first electoral term of the Chamber of Deputies. Factum conducted the fieldwork. There were 146 respondents (i.e. $73 \%$ of the total of $200 \mathrm{MPs}$ ) and in comparison with the previous survey conducted by the department the individual parliamentary groups were more equally represented in the research. 
Table 4. The party structure of the Institute of Sociology survey sample in 1996

\begin{tabular}{lccc}
\hline Parliamentary party group (PPG) & $\begin{array}{c}\text { No. of MPs } \\
\text { in the PPG }\end{array}$ & $\begin{array}{c}\text { No. of interviews } \\
\text { (\% of PPG) }\end{array}$ & $\begin{array}{c}\text { Percentage } \\
\text { of total } \\
\text { interviews }\end{array}$ \\
\hline Civic Democratic Party (ODS) & 72 & $45(63 \%)$ & 30.8 \\
Left Block (LB) & 23 & $22(96 \%)$ & 15.1 \\
Christian-Democratic Union - Czechoslovak & & & \\
People's Party (KDU-ČSL) & 24 & $20(83 \%)$ & 13.7 \\
Czech Social Democratic Party (ČSSD) & 22 & $19(86 \%)$ & 13.0 \\
Civic Democratic Alliance (ODA) & 16 & $11(69 \%)$ & 7.5 \\
$\begin{array}{l}\text { Communist Party of Bohemia and Moravia } \\
\text { (KSČM) }\end{array}$ & 10 & $8(80 \%)$ & 5.5 \\
Czech-Moravian Union of Centre (ČMUS) & 15 & $8(53 \%)$ & 5.5 \\
Civic National Movement (ONAH) & 6 & $6(100 \%)$ & 4.1 \\
Association for the Republic - Czechoslovak & & & \\
Republican Party (SPR-RSČ) & 5 & $1(20 \%)$ & 0.7 \\
No party affiliation & 7 & $6(86 \%)$ & 4.1 \\
Total & 200 & $146(73 \%)$ & 100.0 \\
\hline
\end{tabular}

Source: Data from the Survey of MPs of the Parliament of the Czech Republic in 1996 [Institute of Sociology, Academy of Sciences of the Czech Republic 1996]; author's calculations.

In comparison with the 1993 questionnaire the version of the questionnaire used in 1996 featured some significant changes. The research team, headed by Lubomír Brokl, was nonetheless able to compare the data from 1993 and 1996 and the team made the following observations. According to the researchers, the MPs elected in 1992 represented a standard selection of political parties and various levels of political power and public life. In the exercise of their mandates MPs primarily saw themselves as the representatives of the voters of their party. MPs considered political parties to be the dominant actors in the articulation of democracy and the mediation of citizens' interests. Although they considered the initiatives submitted by various social groups to be important, they also felt that their practical significance in parliamentary work had declined [see Kroupa 1996; Brokl, Mansfeldová and Kroupa 1998].

\section{From 1996 to 2004: Studies on the Chamber of Deputies by Lubomír Brokl's research team}

In 1998 the Sociology of Politics Department at the Institute of Sociology conducted their third survey of MPs, again headed by Lubomír Brokl. This survey of deputies was financially supported by the Institute of Sociology and was carried out in the spring of 1998, before the early elections of that year, so the data of the second term of the Chamber of Deputies were not lost. Interviewers from Sofres-Fac- 
Table 5. The party structure of the Institute of Sociology survey sample in 1998

\begin{tabular}{lccc}
\hline Parliamentary party group (PPG) & $\begin{array}{c}\text { No. of MPs } \\
\text { in the PPG }\end{array}$ & $\begin{array}{c}\text { No. of interviews } \\
\text { (\% of PPG) }\end{array}$ & $\begin{array}{c}\text { Percentage } \\
\text { of total } \\
\text { interviews }\end{array}$ \\
\hline Czech Social Democratic Party (ČSSD) & 58 & $55(95 \%)$ & 34.2 \\
$\begin{array}{l}\text { Civic Democratic Party (ODS) } \\
\text { Union of Freedom (US) }\end{array}$ & 38 & $36(95 \%)$ & 22.4 \\
$\begin{array}{l}\text { Communist Party of Bohemia and Moravia } \\
\text { (KSČM) }\end{array}$ & 29 & $24(83 \%)$ & 14.9 \\
$\begin{array}{l}\text { Christian-Democratic Union - Czechoslovak } \\
\text { People's Party (KDU-ČSL) }\end{array}$ & 19 & $21(95 \%)$ & 13.0 \\
$\begin{array}{l}\text { Civic Democratic Alliance (ODA) } \\
\text { Association for the Republic - Czechoslovak }\end{array}$ & 12 & $15(79 \%)$ & 9.3 \\
$\begin{array}{l}\text { Republican Party (SPR-RSČ) } \\
\text { No party affiliation }\end{array}$ & 18 & $6(50 \%)$ & 3.7 \\
Total & 4 & $0(0 \%)$ & 0.0 \\
\hline
\end{tabular}

Source: Data from the Survey of MPs of the Parliament of the Czech Republic in 1998 [Institute of Sociology, Academy of Sciences of the Czech Republic 1998]; author's calculations.

Table 6. The party structure of the Institute of Sociology survey sample in 2000

\begin{tabular}{lccc}
\hline Parliamentary party group (PPG) & $\begin{array}{c}\text { No. of MPs } \\
\text { in the PPG }\end{array}$ & $\begin{array}{c}\text { No. of interviews } \\
\text { (\% of PPG) }\end{array}$ & $\begin{array}{c}\text { Percentage } \\
\text { of total } \\
\text { interviews }\end{array}$ \\
\hline Czech Social Democratic Party (ČSSD) & 74 & $65(88 \%)$ & 37 \\
$\begin{array}{l}\text { Civic Democratic Party (ODS) } \\
\begin{array}{l}\text { Communist Party of Bohemia and Moravia } \\
\text { (KSČM) }\end{array}\end{array}$ & 63 & $56(89 \%)$ & 31.5 \\
$\begin{array}{l}\text { Christian-Democratic Union - Czechoslovak } \\
\text { People's Party (KDU-ČSL) }\end{array}$ & 24 & $22(92 \%)$ & 12 \\
Union of Freedom (US) & 18 & $18(90 \%)$ & 10 \\
No party affiliation & 1 & $17(94 \%)$ & 9 \\
Total & 200 & $179(90 \%)$ & 0.5 \\
\hline
\end{tabular}

Source: Data from the Survey of MPs and Senators of the Parliament of the Czech Republic in 2000 [Institute of Sociology, Academy of Sciences of the Czech Republic 2000]; author's calculations.

tum interviewed MPs during the 24th meeting of the Chamber of Deputies; the final interviews even took place as late as May 1998. A total of 161 interviews were carried out (i.e. $80.5 \%$ of the $200 \mathrm{MPs}$ ). The entire parliamentary party group of SPRRSC refused to take part in the research [see Seidlová 1999]. Since 1996 the questionnaire used by the Institute of Sociology's research team has been approximately $90 \%$ comparable with subsequent versions. 
The survey in 2000 was organised by a research team from the Sociology of Politics Department under the direction of Lubomír Brokl. Data collection was conducted with the financial support of the Grant Agency of the Czech Republic (grant no. 407/00/0747 'Deputies and Senators of the Parliament CR in the Third Term') and the Grant Agency of the Academy of Sciences of the Czech Republic (grant no. S7028003 'Documentary Centre for Parliamentary Research'). The survey was unique in that for the first time it encompassed both senators and MPs. The research in the Chamber of Deputies took place during its 26th meeting (27 June $2000-11$ July 2000). A total of 179 interviews were conducted $(89.5 \%$ of the total number of 200 deputies), including the deputy chair, three political party chairs, and ten chairs and forty-five deputy chairs of parliamentary committees. In 2000 the research group carried out the survey itself (for more on the research see Seidlová [2001a] and Seidlová [2001b]).

The fieldwork in the Senate took place on 19 October at a meeting of the Senate from 19 to 26 October 2000, and 73 interviews were carried out (i.e. $90.1 \%$ out of the total of 81 senators), and among the respondents were chairs, four deputy chairs, one chair of a political party, five chairs and twenty-five deputy chairs of Senate committees, nine chairs of Senate sub-committees and four chairs of delegations.

In this phase of research new subjects were added relating to the mutual relationship between MPs and senators, the position of the Senate in the Czech constitutional system, the position and powers of the President, and the newly created self-governing regions. The questionnaires used for MPs and senators are almost fully comparable. The main findings in these studies were published in two volumes containing the proceedings of conferences held in the Chamber of Deputies [Brokl 2001] and the Senate [Mansfeldová 2001]. The data were also used in a study dealing with parliamentary party group voting [Linek and Rakušanová 2002; Linek and Rakušanová 2004], the role of parliamentary committees and how they function [Mansfeldová, Syllová, Rakušanová and Kolář 2003; Rakušanová 2001], the accountability of MPs [Brokl, Mansfeldová and Seidlová 2001], asserting agricultural interests in the Czech Republic [Rakušanová 2002b] and generally the role of par-

Table 7. Party structure of the Institute of Sociology survey sample in 2000

\begin{tabular}{lccc}
\hline Parliamentary party group (PPG) & $\begin{array}{c}\text { No. of MPs } \\
\text { in the PPG }\end{array}$ & $\begin{array}{c}\text { No. of interviews } \\
\text { (\% of PPG) }\end{array}$ & $\begin{array}{c}\text { Percentage } \\
\text { of total } \\
\text { interviews }\end{array}$ \\
\hline ODS & 24 & $24(100 \%)$ & 29.6 \\
ČSSD & 23 & $16(70 \%)$ & 28.4 \\
KDU-ČSL & 17 & $16(94 \%)$ & 21.0 \\
US-ODA & 11 & $11(100 \%)$ & 13.6 \\
No party affiliation & 6 & $6(100 \%)$ & 7.4 \\
Total & 81 & $73(90 \%)$ & 100.0 \\
\hline
\end{tabular}

Source: Data from Survey of MPs and Senators of the Parliament of the Czech Republic in 2000 [Institute of Sociology, Academy of Sciences of the Czech Republic 2000]; author's calculations. 
Table 8. The party structure of the Institute of Sociology survey sample in 2003

\begin{tabular}{|c|c|c|c|}
\hline Parliamentary party group (PPG) & $\begin{array}{l}\text { No. of MPs } \\
\text { in the PPG }\end{array}$ & $\begin{array}{l}\text { No. of interviews } \\
\text { (\% of PPG) }\end{array}$ & $\begin{array}{l}\text { Percentage } \\
\text { of total } \\
\text { interviews }\end{array}$ \\
\hline Czech Social Democratic Party (ČSSD) & 70 & $57(81 \%)$ & 33.7 \\
\hline Civic Democratic Party (ODS) & 58 & $47(81 \%)$ & 27.8 \\
\hline $\begin{array}{l}\text { Communist Party of Bohemia and Moravia } \\
\text { (KSČM) }\end{array}$ & 41 & $38(93 \%)$ & 22.5 \\
\hline $\begin{array}{l}\text { Christian-Democratic Union - Czechoslovak } \\
\text { People's Party (KDU-ČSL) }\end{array}$ & 21 & 17 (81\%) & 10.1 \\
\hline $\begin{array}{l}\text { Union of Freedom - Democratic Union } \\
\text { (US-DEU) }\end{array}$ & 10 & $10(100 \%)$ & 5.9 \\
\hline Total & 200 & $169(85 \%)$ & 100.0 \\
\hline
\end{tabular}

Source: Data from the Survey of MPs of the Parliament of the Czech Republic in 2003 [Institute of Sociology, Academy of Sciences of the Czech Republic 2003]; author's calculations.

ties in the political system of the Czech Republic [Mansfeldová 2002a, 2002b; Rakušanová 2002a].

The last survey to date on MPs' attitudes was conducted in October 2003. The data in this survey were collected by a research team at the Institute of Sociology headed by Lubomír Brokl. The survey was conducted with the support of the Grant Agency of the Academy of Sciences of the Czech Republic (grant no. S7028003 'Documentary Centre for Parliamentary Research'). A total of 169 MPs responded to the questionnaire survey, and all of the parliamentary parties were relatively equally represented. The content of the questionnaire was slightly changed from the versions used in previous years. The main innovation was the inclusion of fifteen questions on attitudes relating to serious issues of public policy (social policy, the level of taxation, individual accountability, the role of the church and morality in society, relationship to the environment, etc.). The data were applied in a study on state budget preparations in the Czech Republic [Mansfeldová and Rakušanová 2005].

\section{Conclusion}

Since 1993 a total of eight questionnaire surveys have been conducted in the Czech parliament, seven of which targeted MPs and only one focused on senators. The data that were gathered in the research comprise a large database that can be used both in research on the evolution of Czech parliamentarism and the establishment of political institutions and party competition and in international comparative studies. They have already served as a source for numerous important studies on parliamentarism, the party competition, how the political parties operate in parliament, and the relationship between political institutions in the Czech Republic. 
LUKÁŠ LINEK is a researcher in the Department of the Sociology of Politics at the Institute of Sociology AS CR and a graduate student in the Department of Sociology at the Faculty of Social Sciences, Charles University. His research focuses on electoral behaviour in multi-level systems, political participation and political parties.

\section{References}

Brokl, Lubmír (ed.). 2001. Deputies, Senators and Integration of the Czech Republic into the European Union. Prague: Institute of Sociology Czech Academy of Sciences.

Brokl, Lubomír, Zdenka Mansfeldová and Aleš Kroupa. 1998. Poslanci proního českého parlamentu (1992-1998). (MPs in the First Czech Parliament 1992-1998) Pracovní texty / Working Papers 98: 5. Prague: Sociologický ústav AV ČR.

Brokl, Lubomír, Zdenka Mansfeldová and Adéla Seidlová. 2001. “Vztah poslanců českého parlamentu v voličům jako problém vertikální odpovědnosti." (The Relationship between MPs in the Czech Parliament and Voters as an Issue of Vertical Accountability) Sociologický časopis 37 (3): 297-312.

Institute of Sociology, Academy of Sciences of the Czech Republic. 1993. A Survey of MPs in the Parliament of the Czech Republic in 1993 [computer file].

Institute of Sociology, Academy of Sciences of the Czech Republic. 1996. A Survey of MPs in the Parliament of the Czech Republic in 1996 [computer file].

Institute of Sociology, Academy of Sciences of the Czech Republic. 1998. A Survey of MPs in the Parliament of the Czech Republic in 1998 [computer file].

Institute of Sociology, Academy of Sciences of the Czech Republic. 2000. A Survey of MPs and Senators in the Parliament of the Czech Republic in 2000 [computer file].

Institute of Sociology, Academy of Sciences of the Czech Republic. 2003. A Survey of MPs in the Parliament of the Czech Republic in 2003 [computer file].

Kopecký, Petr. 1993. The Institutionalisation of Parliamentary Democracy in Poland, Hungary, the Czech Republic and Slovakia 1993 [computer file for the Czech Republic].

Kopecký, Petr. 2001. Parliaments in the Czech and Slovak Republics. Party Competition and Parliamentary Institutionalization. Aldershot, Hampshire: Ashgate.

Kroupa, Aleš. 1996. Poslanci, voliči a politické strany. (MPs, Voters, and Political Parties) Data \& Facts Edition 4/1996. Prague: Sociologický ústav AV ČR.

Linek, Lukáš and Petra Rakušanová. 2002. Parties in the Parliament. Why, When and How Do Parties Act in Unity? Parliamentary Party Groups in the Chamber of Deputies in the Years 1998-2002. Sociological Texts Edition. Prague: Sociologický ústav AV ČR.

Linek, Lukáš and Petra Rakušanová. 2004. “The More Parties Vote and the Bigger Their Majority Is, the Less United They Are." Pp. 102-119 in Central European Parliaments: First Decade of Democratic Experience and Future Perspectives, edited by Zdenka Mansfeldová, David M. Olson and Petra Rakušanová. Prague: Sociologický ústav AV ČR.

Mansfeldová, Zdenka (ed.). 2001. Relationship of the Chamber of Deputies and Senate. Prague: Sociologický ústav AV CR.

Mansfeldová, Zdenka. 2002a. “Das tschechische Parlament im Zeichen allmählicher Stabilisierung." Pp. 111-126 in Parlamente und Systemtransformation im Postsozialistischen Europa, edited by Susanne Kraatz and Silvia von Steinsdorff. Opladen: Leske and Budrich.

Mansfeldová, Zdenka. 2002b. “Die Tschechische Republik." Pp. 385-411 in Vom Baltikum zum Schwarzen Meer. Transformation im östlichen Europa, edited by Anneli Ute Gabanyi and Klaus Schroeder. München: Bayerische Landeszentrale für politische Bildungsarbeit. 
Mansfeldová, Z., J. Syllová, P. Rakušanová and P. Kolár. 2003. “Committees of the Parliament of the Czech Republic." Pp. 69-89 in Committees in Post-Communist Democratic Parliaments: Comparative Institutionalism, edited by David M. Olson and William E. Crowther. Columbus: Ohio State University Press.

Mansfeldová, Z. and P. Rakušanová. 2005. "Legislative Budgeting in the Czech Republic." A paper prepared for the Annual Meeting of the Southern Political Science Association on 6-8 January 2005, in New Orleans, United States. K-10/B-9 Roundtable: The Role of Parliaments in the Budget Process.

Miller, William L., Stephen White, Paul Heywood. 1998. Values and Political Change in Post-communist Europe. London: Macmillan.

Miller, William L., Stephen White, Paul Heywood. 2000. Values and Political Change in Post-communist Europe, 1993-1994 [computer file]. Colchester, Essex: UK Data Archive [distributor]. SN: 4129.

Seidlová, Adéla. 1999. Poslanci Parlamentu České republiky. (MPs in the Parliament of the Czech Republic) Data \& Facts Edition 10/1999. Prague: Sociologický ústav AV ČR.

Seidlová, Adéla. 2001a. "Výzkum poslanců a senátorů Parlamentu ČR. Technické informace o výzkumu." (Research on MPs and Senators in the Parliament of the Czech Republic. Technical Information on the Research) Sociologický časopis 37 (3): 359-368.

Seidlová, Adéla. 2001b. “How Do Female Deputies Differ from Male Deputies?" Berliner Osteuropa Info 16/2001.

Rakušanová, P. 2002a. “Establishment of the Party System and the Party-Voter Linkages: The Case Study of the Czech Republic." Pp. 209-220 in Contemporary Questions of Central European Politics, edited by Ladislav Cabada. Plzeň: Vydavatelství a nakladatelství Aleš Čeněk.

Rakušanová, P. 2002b. “Reprezentace zemědělských zájmů v legislativním procesu Parlamentu ČR" (The Representation of Agricultural Interests in the Legislative Process of the Parliament of the Czech Republic). Pp. 43-50 in Reprezentace zemědělských zájmů v českém stranickém systému po roce 1989, edited by Petr Blažek. Prague: Česká zemědělská univerzita.

Rakušanová, P. 2001. “Úloha a postavení výborů PS PČR v procesu transformace.” (The Role and the Position of the Committees of the Chamber of Deputies of the Czech Republic during the Period of Transformation) Politologický časopis 8 (1): 95-105. 